Participatory Educational Research (PER)

Vol. 5(2), pp. 95-117, December, 2018

Available online at http://www.perjournal.com

ISSN: 2148-6123

http://dx.doi.org/10.17275/per.18.14.5.2

\title{
Middle School Students' Perceptions about the Scientists
}

\author{
Aykut Emre Bozdoğan* \\ Tokat Gaziosmanpaşa University, Faculty of Education, Tokat, Turkey \\ Ümmü Gülsüm Durukan \\ Giresun University, Faculty of Education, Giresun, Turkey
}

Yasemin Hacioğlu

Giresun University, Faculty of Education, Giresun, Turkey

Article history
Received:

21.11.2018

Received in revised form:

25.12.2018

Accepted:

26.12.2018

Key words:

Scientist's image, Middle

school student,

Questionnaire for

Evaluation of Scientists
This study aimed at in-depth examination of middle school students' perceptions about the scientists. The study was carried out with survey model. The data of the study were gathered via "Questionnaire for Evaluation of Scientists (QES)" and focus group interviews. The data were analysed quantitatively and the quantitative data were qualitatively supported with quotations and interviews' data. . The study group is consisted of 1011 middle school students from different cities in Turkey. According to the studies, students' perceptions about the scientists were mostly similar to the results. 1011 middle school students in different grades have similar perceptions but their image of the scientists' scores low. The students' images of a scientist had positive features such as intelligent and imaginative but they had also negative images like boring. Students think that a scientist was not very religious or did not believe in God. The students had positive views when they evaluated themselves as a scientist. It was observed that the physical features of the students' image of scientists were males, in their $30 \mathrm{~s}$, with strange hair style and an ordinary look, and wearing glasses, beard/moustache, and a lab coat. They thought that the scientists were interested in invention, research and experiment and worked in a laboratory. As the source of their images, they stated scientists' life stories, the internet, course books, science journals, and films.

\section{Introduction}

Due to the requirements of the knowledge era, developing each individual's skills for doing science has become important. The science education curriculum in Turkey, implemented and revised in 2013, emphasize the working processes of scientists in the following goals: "To help students understand how scientists create scientific knowledge, the process through which the generated knowledge goes, and how it is used in new scientific research" and "To make contributions to understanding that science has been produced as a result of joint effort by many scientists from all cultures and to develop the feeling of appreciation of scientific studies" (MNE, 2013: 2). Moreover, national and international 
science education programs aim to educate scientifically literate individuals and they have adopted inquiry based learning approach (Gormally, Brickman, Hallar \& Armstrong, 2009). Based on the inquiry-based approach, students gain scientific process skills used by the scientists during their studies and create knowledge in their minds via learning through experience and thinking like a scientist. This means that students see the world through a scientist's eye, so students should have positive images about scientists (Kaya, Doğan \& Öcal, 2008). Individuals' cognitive images and perceptions about scientists have an important effect on their attitudes towards science (Finson, 2002; Kahle, 1989). It was revealed in the studies that science and scientist's images had complex structures and school and textbooks (A ğgülYalçın, 2012; Finson, 2002; Karaçam, Aydın \& Digilli, 2015; She, 1995; Song \& Kim, 1999; Türkmen, 2008), teacher's behaviours and personality (Akcay, 2011; Buldu, 2006; Song \& Kim, 1999; Türkmen, 2008), informal activities (Buluş-Kırıkkaya, Bozkurt \& İșeri, 2011), television and cartoons/films (Ağgül-Yalçın, 2012; Chambers, 1983; Finson, 2002; Güler \& Akman, 2006; Song \& Kim, 1999; Türkmen, 2008), the Internet (A ğgül-Yalçın, 2012; Finson, 2002), museum and field trips (Ağgül-Yalçın, 2012; Song \& Kim, 1999), scientist's biographies (Ağgül-Yalçın, 2012; Finson, 2002; Song \& Kim, 1999), science newspaper/journals/books (A ğgül-Yalçın, 2012; Chambers, 1983; Finson, 2002; Song \& Kim, 1999; Türkmen, 2008), culture (Akcay, 2011; Jones, Howe \& Rua, 2000) and human relationships (Jones, Howe \& Rua, 2000; Song \& Kim, 1999; Türkmen, 2008) affected on them. The first attempt to summarize this complex structure, the study conducted by Mead and Metraux's (1957) and they identified the elements of the image of the scientist with their findings, as in the following sentences (a cited in Song and Kim, 1999):

The scientist is a man who wears a white coat and works in a laboratory. He is elderly or middle aged and wears glasses. He is small, sometimes small and stout, or tall and thin. He may be bald. He may wear a beard, may be unshaven and unkempt. He may be stooped and tired. He is surrounded by equipment: test tubes, bunsen burners, flasks and bottles, a jungle gym of blown glass tubes and weird machines with dials... He spends his days doing experiments. He pours chemicals from one test tube into another. He peers raptly through microscopes. He scans the heavens through a telescope [or a microscope!]. He experiments with plants and animals, cutting them apart, injecting serum into animals.

Similarly, Chambers (1983) generalized the children's image of the scientist as follows: Generally a man who is wearing a white lab coat, unshaven or unkempt, with eye glasses and beard, using computer, microscope, or telescope, symbols of research like scientific instruments and different laboratory equipment, and symbols of knowledge like books/filing cabinets or shelves of books as well as formulae and descriptive verbal expression of the scientist...

In another study, Newton and Newton (1992) re-classified the drawing's background features as well as children's image of the scientist like his gender, lab coat, glasses, beard and baldness. These include the following:

...regarding background, there is usually laboratory equipment like experiment tubes related to scientific knowledge and research, living species made up of animals and plants, objects related to space like stars and planets, and technological products such as robots. Background features involving scientific process like observation, measurement, recording and transmitting, and thinking also draw attention...

When literature was analysed, it was found that a lot of national and international studies were conducted to determine the cognitive images and perceptions about a scientist of participants at different levels of education; pre-school (Buldu, 2006; Güler, \& Akman, 2006;), elementary (Akcay, 2011; Buldu, 2006; Buluş-Kırıkkaya, et al. 2011; Camc1-Erdoğan, 2013a, 2013b; Fralick, Kearn, Thompson \& Lyons, 2009; Fung, 2002; Gunsolin, 2001; Huber, \& Burton, 1995; Kaya et. al. 2008; Kibar-Kavak, 2008; Korkmaz, \& Kavak, 2010; Medina- 
Jerez, Middleton \& Orihuela-Rabaza, 2011; Monhardt, 2003; Nuhoğlu \& Afacan, 2011; Öcal, 2007; Song, \& Kim, 1999; She, 1995; Türkmen, 2008; Ünver, 2010; Yontar-Toğrol, 2013), high school (Akcay, 2011; Barman, 1999; Fung, 2002; Song, \& Kim, 1999; Parsons, 1997; Thomas \& Hairston, 2003), pre-service teachers (Ağgül-Yalçın, 2012; Finson, 2002; Moseley \& Norris, 1999; Ünver, 2010) and in-service teachers (Finson, 2002). These studies that are done determine the image of the students shed light to educators on how to motivate the students to become scientist (Korkmaz \& Kavak, 2010). Except for a few different findings, many of these studies revealed that participants had similar images of a scientist. A considerable number of these studies in literature used the tests developed by Chambers (1983) and Song and Kim (1999) and they focused on determining the participants' images of the scientist. At this point, although a lot of studies have been carried out in literature to identify the participants' images of a scientist at different levels of education, relatively very few studies have examined the images of a scientist in detail. Thus, this study aimed at revealing secondary school students' perceptions about the scientist to examine the image of a scientist in detail. The research question was "What are the middle school students" perceptions about a scientist?".

\section{Method}

\section{The Research Model}

This study was carried out with survey model, one of the descriptive research methods. Survey method is a research approach which aims at describing a past or an existing situation. A phenomenon, an individual, or an object becomes the subject of the research are described within their own conditions and as they are (Cohen, Manion, \& Morrison, 2000).

\section{The Study Group}

The study was included in 20 middle schools that are selected among by easily accessible schools located in 8 different cities (Adıyaman, Balıkesir, Giresun, Kayseri, Kırşehir, Muğla, Samsun, Şırnak) in Turkey. $10116^{\text {th }}, 7^{\text {th }}$ and $8^{\text {th }}$ grade students participated in the study and their age range was between 12 and 15 . The distribution of respondents regarding their gender and grades are shown in Table 1.

Table 1. The distribution of respondents regarding their grades and gender (n)

\begin{tabular}{lllll}
\hline & \multicolumn{3}{c}{ Grades frequency (f) } & \\
\cline { 2 - 4 } Gender & $\mathbf{6}^{\text {th }}$ & $\mathbf{7}^{\text {th }}$ & $\mathbf{8}^{\text {th }}$ & Total \\
\hline Male students & 169 & 142 & 166 & 477 \\
\hline Female students & 187 & 159 & 188 & 534 \\
\hline Total & 356 & 301 & 354 & 1011
\end{tabular}

\section{Data Collection Tools and Data Analysis}

The data of the study were collected using "Questionnaire for Evaluation of Scientists (QES)" which was administered to 1011 students and focus group interviews were carried out with 39 students.

\section{Questionnaire for Evaluation of Scientists (QES)}

When the literature examined, "The Draw -a- Scientist Test" (DAST) developed by Chambers (1983) was found to reveal children's ideas of the scientist. This test was used by many researchers to investigate children's perceptions and images of the scientist at different age groups and it does not require reading and writing skills, so the important advantage of this test is that it considerably decreases obtaining socially expected responses (She, 1995). 
Similarly, Schibeci \& Sorensen (1983) in their studies stated that DAST scale was useful for evaluating children's opinions. Another test was developed by Song and Kim (1999) taking advantage of DAST.

In this study, the "Questionnaire for Evaluation of Scientists (QES)" was extended by studies of Chambers (1983) and Song and Kim (1999). The content of the questions, their features and data analysis included in QES are presented in Table 2.

Table 2. The content of the questions and their features included in QES

\begin{tabular}{|c|c|c|c|c|c|c|c|}
\hline 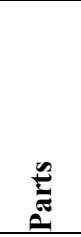 & \multicolumn{2}{|c|}{ Questions } & \multirow[t]{2}{*}{ 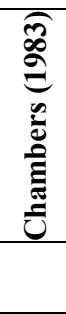 } & \multirow{2}{*}{ 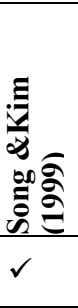 } & 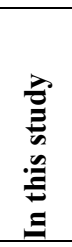 & Question type & \multirow{2}{*}{$\begin{array}{l}\text { Data Analysis } \\
\text { Average point- } \\
\text { Correlation }\end{array}$} \\
\hline$\ddot{n}$ & Q1 & $\begin{array}{l}\text { a. Images of the scientist } \\
\text { "How do you think the scientist would be?" }\end{array}$ & & & $\checkmark$ & $\begin{array}{l}\text { Five point Likert } \\
\text { scale }\end{array}$ & \\
\hline$\cdot \frac{\overrightarrow{0}}{0}$ & & $\begin{array}{l}\text { b. Self-assessment images of the scientist } \\
\text { "If you were a scientist, how would you be?" }\end{array}$ & & & $\checkmark$ & $\begin{array}{l}\text { Five point Likert } \\
\text { scale }\end{array}$ & $\begin{array}{l}\text { Average point- } \\
\text { Correlation }\end{array}$ \\
\hline 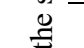 & Q2 & a. gender of the scientist & $\checkmark$ & $\checkmark$ & $\checkmark$ & Classification & Frequency \\
\hline 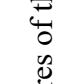 & & b. age of the scientist & $\checkmark$ & $\checkmark$ & $\checkmark$ & $\begin{array}{l}\text { Equal } \\
\text { proportional }\end{array}$ & Frequency \\
\hline 莺 & & $\begin{array}{l}\text { c. activity of the scientist } \\
\text { "What is he/she doing?" }\end{array}$ & $\checkmark$ & $\checkmark$ & $\checkmark$ & Open -ended & Content \\
\hline$\stackrel{1}{E}$ & & $\begin{array}{l}\text { d. activity place of the scientist } \\
\text { "Where's the background of the drawing?" }\end{array}$ & $\checkmark$ & $\checkmark$ & $\checkmark$ & Open -ended & Content \\
\hline & & e. features of appearance & $\checkmark$ & $\checkmark$ & $\checkmark$ & Drawing & Content \\
\hline 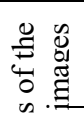 & Q3 & $\begin{array}{l}\text { source of the scientist's image } \\
\text { "What do you think your image of scientist expressed } \\
\text { in previous questions was influenced most from?" }\end{array}$ & & $\checkmark$ & $\checkmark$ & Multiple choice & Content \\
\hline 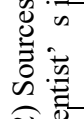 & Q4 & $\begin{array}{l}\text { scientists around us } \\
\text { "Who can be regarded as 'the scientist' around you? } \\
\text { And you? (Who, Why)" }\end{array}$ & & $\checkmark$ & $\checkmark$ & Open-ended & $\begin{array}{l}\text { Frequency } \\
\text { Content }\end{array}$ \\
\hline$\widehat{\tilde{E}} \cdot \overline{\tilde{u}}$ & Q5 & $\begin{array}{l}\text { favourite scientist(s) } \\
\text { "Who is your favourite scientist? (Scientist, Why)" }\end{array}$ & & $\checkmark$ & $\checkmark$ & Open-ended & $\begin{array}{l}\text { Frequency } \\
\text { Content }\end{array}$ \\
\hline 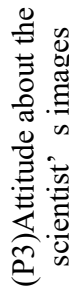 & Q6 & $\begin{array}{l}\text { Being a scientist } \\
\text { "Do you want to be a scientist? Why?" }\end{array}$ & & & $\checkmark$ & Open-ended & $\begin{array}{l}\text { Frequency } \\
\text { Content }\end{array}$ \\
\hline
\end{tabular}

The data obtained from all the sections of the study were examined separately considering the differences in terms of gender and grades. For all tables in the text, the value (f or $\%$ or mean score) in the table is stated in the title of table.

\section{Focus group interview}

There is no explanation in literature considering the question (Q1a) which asked whether a scientist is religious or not. Because of gathering in-depth information about this issue, the focus group interviews were carried out with in six interview groups - 39 students who were randomly chosen from the $6^{\text {th }}, 7^{\text {th }}$, and $8^{\text {th }}$ grades. Students were asked the questions "Are scientists religious or not? Why?". The stereotyped data obtained from the focus group interviews were transcripted and examined via content analysis, one of the qualitative research methods, and the codes were presented in Table 5. 


\section{Validity \& Reliability}

For providing this study's validity and reliability, the following steps were performed:

- While extending QES for middle school students, the expert opinions were taken.

- The data analysed and constituted codes and themes by two researchers and the third researcher verified the analysis. Then, the final version of the analysis was given by ensuring the consistency between the researchers.

- The analysis process explained elaborately. Students' quotations were used to exemplify them. When quotations are stated, the students are coded as grades $\left(6^{\text {th }}, 7^{\text {th }}\right.$ or $\left.8^{\text {th }}\right)$, gender $(\mathrm{F}$ or $\mathrm{M})$, number $(1,2, \ldots$, or 1011$)$. For example, the student in grade 6 , female, and number 1 is coded as $6 \mathrm{~F} 1$.

\section{Results}

\section{Q1: The Characteristic features of the scientist}

In the Q1a, students were asked to evaluate their perceptions towards "mental images of the scientists" with twelve five-point likert scale items. In the Q1b, they were also asked to self-assess themselves using the same attributes. The distribution of the answers given by the students is shown in Table 3 .

Table 3. Mental images of the scientist (mean score)

\begin{tabular}{lccccccc}
\hline $\begin{array}{l}\text { Items of the mental images } \\
\text { (scale items) }\end{array}$ & $\mathbf{M}$ & $\mathbf{F}$ & $\mathbf{6}^{\text {th }}$ & $\mathbf{7}^{\text {th }}$ & $\mathbf{8}^{\text {th }}$ & $\begin{array}{c}\text { Q1a } \\
\text { Images of the } \\
\text { scientist (Total) }\end{array}$ & $\begin{array}{c}\text { Self-assessment images of } \\
\text { the scientist (Total) }\end{array}$ \\
\cline { 2 - 7 } 1. Careless-accurate & 4.49 & 4.51 & 4.47 & 4.45 & 4.57 & 4.50 & 4.60 \\
\hline 2. Stupid-intelligent & 4.50 & 4.55 & 4.56 & 4.51 & 4.51 & 4.53 & 4.57 \\
\hline 3. Lazy-industrious & 4.44 & 4.53 & 4.51 & 4.43 & 4.52 & 4.49 & 4.55 \\
\hline $\begin{array}{l}\text { 4. Unimaginative- } \\
\text { imaginative }\end{array}$ & 4.42 & 4.50 & 4.42 & 4.45 & 4.52 & 4.46 & 4.52 \\
\hline 5. Selfish-caring & 4.04 & 4.23 & 4.29 & 3.97 & 4.14 & 4.14 & 4.45 \\
\hline $\begin{array}{l}\text { 6. Closed minded-open } \\
\text { minded }\end{array}$ & 3.99 & 4.02 & 4.05 & 3.87 & 4.09 & 4.01 & 4.10 \\
\hline 7. Boring-exciting & 3.64 & 3.75 & 3.78 & 3.58 & 3.71 & 3.70 & 4.17 \\
\hline 8. Inartistic-artistic & 2.66 & 2.73 & 2.53 & 2.80 & 2.77 & 2.70 & 2.71 \\
\hline 9. Inhumane-humane & 4.15 & 4.24 & 4.26 & 4.13 & 4.18 & 4.20 & 4.53 \\
\hline 10. Irresponsible-responsible & 4.35 & 4.46 & 4.51 & 4.29 & 4.39 & 4.41 & 4.53 \\
\hline 11. Irreligious-religious & 3.57 & 3.57 & 3.75 & 3.49 & 3.47 & 3.57 & 4.20 \\
\hline $\begin{array}{l}\text { 12. Non- peace loving -peace } \\
\text { loving }\end{array}$ & 4.22 & 4.39 & 4.40 & 4.23 & 4.28 & 4.31 & 4.64 \\
\hline Mean & 4.04 & 4.12 & 4.12 & 4.01 & 4.09 & 4.08 & 4.29 \\
\hline
\end{tabular}

Table 3 shows the results of the analysis of "mental images of the scientist". It can be seen that students gave positive scores in nine items such as intelligent (4.53), accurate (4.50), industrious (4.49) and imaginative (4.46). On the contrary, they gave negative scores in the other three items such as "boring (3.70), religious (3.57) and artistic (2.70)". When the total scores for all items are considered, it can be said that students' mental images of the scientists are quite positive (4.08). Additionally, the students assessed themselves as a scientist more positively for all items than the image of the scientist (For the detailed analysis, see Table 4). In Table 3, female students compared to male students had higher average scores with regard to items of selfish-caring, boring-exciting, inhumane-humane, irresponsible-responsible and non- peace loving -peace loving. Moreover, a difference between the average scores for the 
first four items considering the grades does not draw attention. However, it is viewed that the average scores of $5^{\text {th }}, 6^{\text {th }}$ and $7^{\text {th }}$ items for the $7^{\text {th }}$ grade students and $8^{\text {th }}$ item for the $6^{\text {th }}$ grade students were lower. The average scores of the $6^{\text {th }}$ grade students for the $9^{\text {th }}, 10^{\text {th }}, 11^{\text {th }}$ and $12^{\text {th }}$ items were higher than the average scores of the $7^{\text {th }}$ and $8^{\text {th }}$ graders. In addition, Table 3 presents the average scores belonging to the students' image of the scientist and the images they consider as scientists. It was revealed that the students had higher average scores (the difference between two average scores is $>0.1)$ in favour of themselves for 7 items $\left(1^{\text {st }}, 5^{\text {th }}\right.$, $7^{\text {th }}, 9^{\text {th }}, 10^{\text {th }}, 11^{\text {th }}$ and $12^{\text {th }}$ ) out of 12 items. Table 4 presents the findings related to the correlation analysis performed to determine the relation between the features that both images have.

Table 4. The relationship between students' image of the scientist and the self-assessment images of the scientist

\begin{tabular}{llc}
\hline & \multicolumn{2}{c}{ Self-assessment image of the scientist (Q1b) } \\
\hline \multirow{2}{*}{ Images of the scientist (Q1a) } & Pearson Correlation & $.932^{* *}$ \\
\cline { 2 - 3 } & Sig. (2-tailed) & .000 \\
\cline { 2 - 3 } & $\mathrm{N}$ & 12 \\
\hline
\end{tabular}

When Table 4 is examined, it is viewed that there is a high level of positive and meaningful relation between their image of the scientist and their self-assessment image of the scientist $(r=.932, p<.01)$. Considering coefficient of determination $\left(r^{2}=.87\right)$, it can be stated that $87 \%$ of the total variance of their self-assessment of the scientist resulted from their images of the scientist. In Table 3 (Item 11), it is found that students have low points for the scientists' being religious or not. For this reason, the focus group interviews were done and the findings were presented in Table 5.

Table 5. Religion of the scientists (f)

\begin{tabular}{|c|c|c|c|c|}
\hline \multicolumn{3}{|c|}{ Religion of the scientists } & $\mathbf{f}$ & Quotations \\
\hline \multicolumn{3}{|l|}{ 1. Religious } & 13 & \\
\hline \multicolumn{3}{|c|}{ 2. Not very religious } & 6 & $\begin{array}{l}\text { "... because scientists do not have time to pray, I think that they will not be } \\
\text { very religious ( } 6^{\text {th }} \text { grade)", } \\
\text { "... because scientists work with inventions and other things, they can forget } \\
\text { religion. That's why I believe that they are not very religious ( } 7 \text { th grade)", } \\
\text { "To me, due to their work, they cannot find time to spare for religion. In } \\
\text { other words, they believe but they are not keen on religion ( } 8^{\text {th }} \text { grade)". }\end{array}$ \\
\hline \multirow{3}{*}{ 3. Irreligious } & & $\begin{array}{l}\text { Because } \\
\text { religion and } \\
\text { other science } \\
\text { branches are } \\
\text { different } \\
\text { disciplines* }\end{array}$ & 12 & $\begin{array}{l}\text { "... because a religious person is interested in religion. Science and religion } \\
\text { are different from each other. For example, a person who is interested in } \\
\text { religion can say that the Earth is created by the God. But, a scientist can say } \\
\text { that there was a big explosion and he tries to prove it ( } 8^{\text {th }} \text { grade)", }\end{array}$ \\
\hline & & $\begin{array}{l}\text { Because they do } \\
\text { not believe in } \\
\text { God* }\end{array}$ & 5 & $\begin{array}{l}\text { "Because they can conflict with religion. For example, some scientists claim } \\
\text { that the Earth was formed as a result of an explosion. Yet, God created the } \\
\text { Earth. Or how a man was created? Who can make this? Of course only God } \\
\text { can make that ( } 8^{\text {th }} \text { grade)", }\end{array}$ \\
\hline & & $\begin{array}{l}\text { Because they } \\
\text { are not Muslim* }\end{array}$ & 3 & $\begin{array}{l}\text { "... because most of the scientists are not Muslim, but Christians }\left(8^{\text {th }}\right. \\
\text { grade)". }\end{array}$ \\
\hline
\end{tabular}

*Reasons

When the Table 5 is examined, out of 39 students who participated in focus group interviews, 13 of them stated that scientists were religious, 6 of them said that they were not very religious and 20 of them mentioned that they were irreligious. The reasons why scientists were not religious were explained like that by the students: 12 students stated that religion and 
other science branches were different disciplines, 5 students said that scientists did not believe in God and 3 of them stated that scientists were not Muslim.

\section{Q2: The physical features of the scientist}

In Q2, students were asked to evaluate their perceptions of "physical features of the scientists" and to give some captions with relevant information "the gender of the scientist, the age of the scientist and the physical images of the scientist". The distribution of the answers given by the students is shown in Table 6 .

Table 6. The physical features of the scientist (\%)

\begin{tabular}{|c|c|c|c|c|c|c|}
\hline & \multicolumn{2}{|c|}{ Gender } & \multicolumn{3}{|c|}{ Grades } & \multirow[b]{2}{*}{ Total } \\
\hline & $\mathbf{M}$ & $\mathbf{F}$ & $6^{\text {th }}$ & $7^{\text {th }}$ & $\mathbf{8}^{\text {th }}$ & \\
\hline \multicolumn{7}{|l|}{ Gender of the scientist (Q2a) } \\
\hline Male & 91.8 & 62.0 & 78.4 & 72.2 & 77.2 & 76.1 \\
\hline Female & 8.2 & 37.8 & 21.6 & 27.6 & 23.2 & 23.9 \\
\hline \multicolumn{7}{|l|}{ Age of the scientist (Q2b) } \\
\hline $10 \mathrm{~s}$ & 9.3 & 10.8 & 11.6 & 8.7 & 9.7 & 10.1 \\
\hline $20 \mathrm{~s}$ & 20.6 & 22.3 & 23.9 & 24.2 & 16.9 & 21.5 \\
\hline $30 \mathrm{~s}$ & 29.7 & 34.0 & 30.1 & 37.3 & 29.5 & 32.0 \\
\hline $40 \mathrm{~s}$ & 13.1 & 11.7 & 9.7 & 10.1 & 17.2 & 12.4 \\
\hline $50 \mathrm{~s}$ & 17.8 & 14.4 & 16.5 & 15.1 & 16.3 & 16.0 \\
\hline $60 \mathrm{~s}$ & 9.5 & 6.6 & 8.2 & 5.0 & 10.3 & 8.0 \\
\hline Average age & 33.81 & 31.63 & 32.02 & 31.42 & 34.35 & \\
\hline \multicolumn{7}{|c|}{ Physical images of the scientist (Q2e) } \\
\hline Strange hair style & 36.5 & 26.6 & 27.5 & 31.2 & 35.2 & 31.3 \\
\hline Glasses & 21.4 & 22.7 & 23.6 & 19.5 & 22.9 & 22.1 \\
\hline Ordinary look & 14.6 & 21.5 & 19.3 & 20.8 & 15.2 & 18.3 \\
\hline Beard or moustache & 19.1 & 13.2 & 15.9 & 16.5 & 15.7 & 16.0 \\
\hline Kind-hearted look & 8.5 & 16.8 & 13.1 & 11.1 & 14.3 & 12.9 \\
\hline Lab coat & 13.8 & 11.9 & 11.6 & 14.8 & 12.3 & 12.8 \\
\hline Unusual figure & 11.2 & 8.5 & 9.7 & 10.1 & 9.7 & 9.8 \\
\hline Bald & 10 & 7.2 & 9.9 & 5.7 & 9.4 & 8.5 \\
\hline Neat look & 6.1 & 6.6 & 6.2 & 8.4 & 4.9 & 6.4 \\
\hline Dull or stupid & 7.2 & 4.2 & 5.7 & 5.4 & 5.7 & 5.6 \\
\hline Foul or malicious & 3.6 & 1.3 & 2.3 & 2.7 & 2.3 & 2.4 \\
\hline Other & 3.4 & 3.6 & 1.1 & 5.0 & 4.6 & 3.5 \\
\hline No response & 7 & 4.5 & 5.4 & 6.0 & 5.7 & 5.7 \\
\hline
\end{tabular}

Table 6 shows that nearly three quarters of the students $(76.1 \%)$ identified the scientist as a male while only $23.9 \%$ did as a female. There was a clear difference in perceptions of the scientists' gender. Especially female students drew female scientists at a much higher rate $(37.8 \%)$ and only $8.2 \%$ of female scientists were drawn by male students. According to these findings, it can be concluded that students (female and male) mostly imagined scientists as male. On the other hand, it can be seen that the ages of the scientists drawn ranged between 10 and 60 . Most students thought that the scientists would be particularly in their $30 \mathrm{~s}$, on average. Male students and the $8^{\text {th }}$ grade students think that scientists are slightly older. According to the findings, the scientists drawn were middle aged. 
The scientist pictures drawn by the students had "strange hair style" (31.3\%), "glasses" (22.1\%), "ordinary look" (18.3\%), "beard or moustache" (16\%), "kind-hearted look" $(12.9 \%)$ and "lab coat" (12.8\%). These were the most popular features of the physical images of the scientist. Students also expressed some contrasting feelings towards the appearance of the scientist. For example, they indicated "bald", "neat look" and "foul or malicious" etc. images of the scientist. The followings are some examples of the pictures drawn by the students (Figure 1).

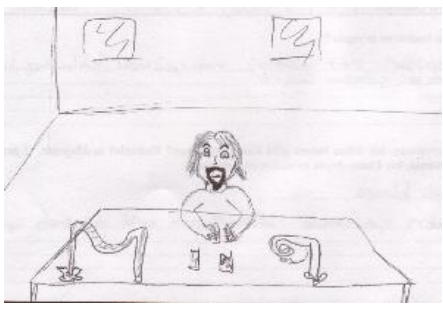

Beard or moustache (7F54)

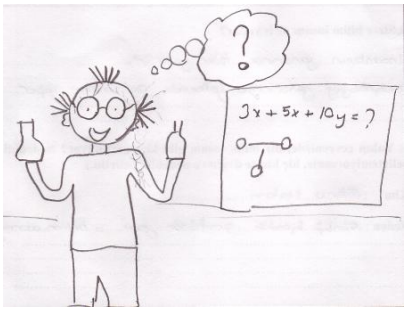

Glasses (8F286)

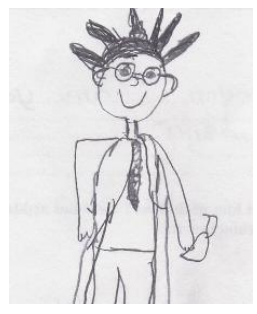

Strange hair style (6M768)

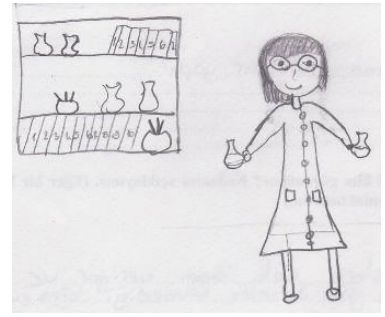

Lab coat $(6 \mathrm{~F} 647)$

Figure 1. Physical images of the scientist

When Table 6 is examined regarding average scores considering the scientist's age, female students determined that they were much younger (in their10s, 20s and 30s) but male students stated that they were much older (in their 50s and 60s). According to their grades, $8^{\text {th }}$ grade students stated that scientists were in their $30 \mathrm{~s}$ and $40 \mathrm{~s}$ and $6^{\text {th }}$ and $7^{\text {th }}$ graders stated that they were in their 20s and 30s. Regarding the physical images of the scientists, male students identified them with strange hair style, beard or moustache, unusual figure and features like bald, dull or stupid and foul or malicious but female students stated that they wore glasses and had ordinary look, kind-hearted look, and neat look, so they had higher average scores. Taking into consideration their grades, it was seen that $7^{\text {th }}$ grade students had low average scores for their features such as glasses, kind-hearted look and bald and $8^{\text {th }}$ graders with their ordinary look feature. Strange hair style was mostly stated by the $8^{\text {th }}$ grade students. In Table 7, students' perceptions of "other physical features of the scientists" like activity, place and background of the drawing are presented.

Table 7. Other physical features of the scientist (\%)

\begin{tabular}{lcccccc}
\hline & \multicolumn{2}{c}{ Gender } & \multicolumn{3}{c}{ Grades } & Total \\
\cline { 2 - 6 } & $\mathbf{M}$ & $\mathbf{F}$ & $\mathbf{6}^{\text {th }}$ & $\mathbf{7}^{\text {th }}$ & $\mathbf{8}^{\text {th }}$ & \\
\hline Activity of the scientist (Q3c) & & & & & & \\
\hline Invention & 37.5 & 31.6 & 41.5 & 40.3 & 22.3 & 34.4 \\
\hline Research & 16.3 & 21.0 & 12.2 & 15.5 & 28.3 & 18.8 \\
\hline Experiment & 13.6 & 15.7 & 17.9 & 13.8 & 12.3 & 14.7 \\
\hline Thinking & 5.3 & 9.3 & 6.8 & 6.7 & 8.6 & 7.4 \\
\hline Teaching & 3.2 & 7.2 & 8.0 & 4.7 & 3.1 & 5.3 \\
\hline Others & 21.4 & 12.5 & 11.6 & 16.8 & 21.7 & 16.7 \\
\hline No response & 3.0 & 2.5 & 1.4 & 2.7 & 4.0 & 2.7 \\
\hline
\end{tabular}


Table 7 (continue). Other physical features of the scientist (\%)

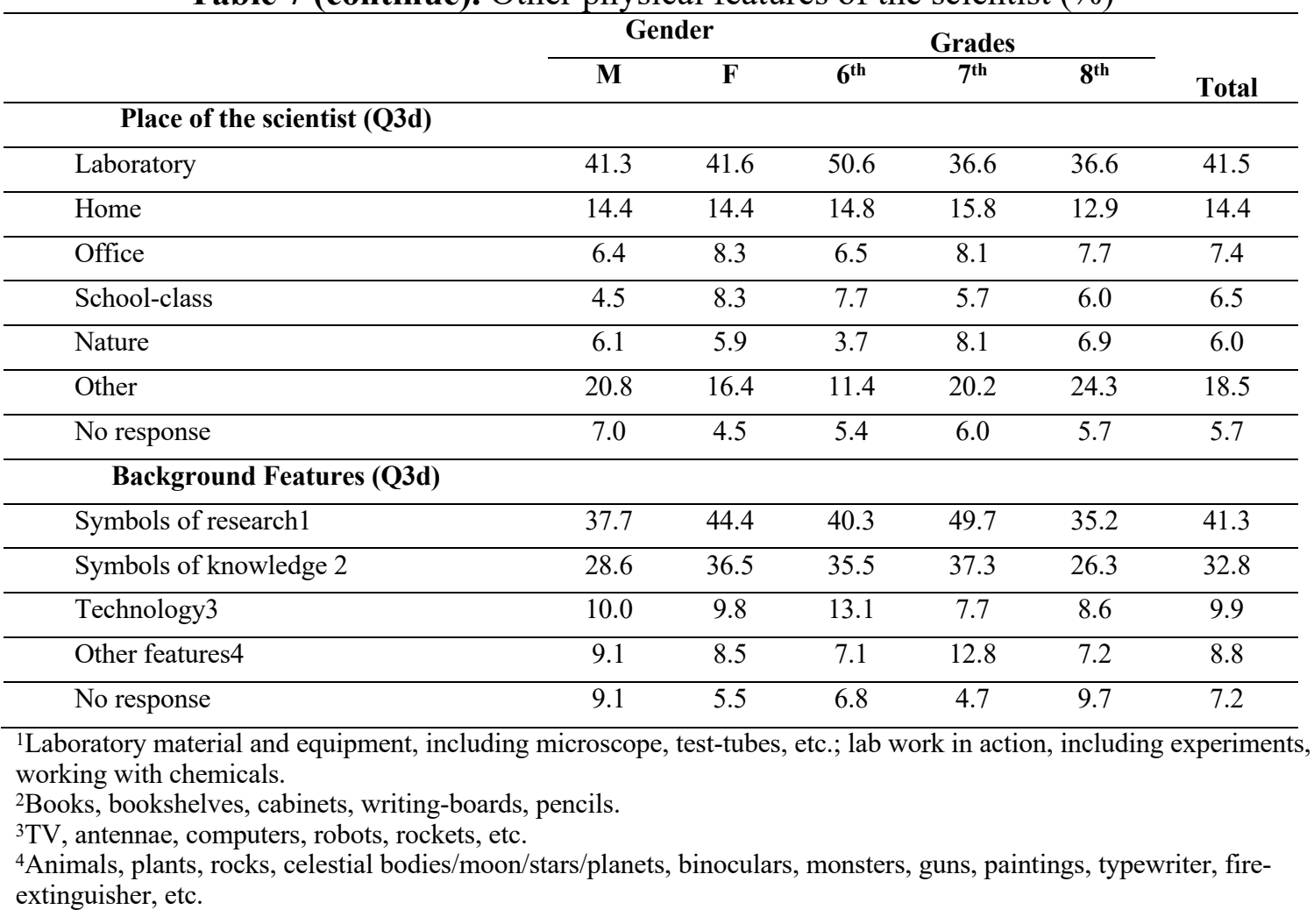

Table 7 shows the distribution of the scientists' activities described by the students in their drawings. The most common responses were "invention" (34.4\%), "research" (18.8\%), "experiment" (14.7\%), "thinking" (7.4\%) and "teaching" (5.3\%). With increasing grades "invention" and "teaching" decreased considerably but "research" increased consistently. Furthermore, a few students drew scientists as operating, taking photos, reading, making drugs, shopping, eating, painting, watching TV, talking with friends, walking, smiling, dead, sleeping or doing observation. For the activity of scientist, the female students mostly drew research, experiment; thinking and teaching but the male students mostly drew invention. Regarding grades, the $6^{\text {th }}$ grade students expressed mostly invention, experiment, and teaching and the $8^{\text {th }}$ grade students determined mostly research and thinking. The figure below is an example of scientist pictures drawn while experimenting:

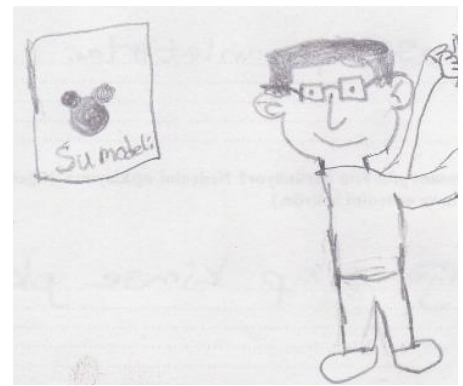

7 F786

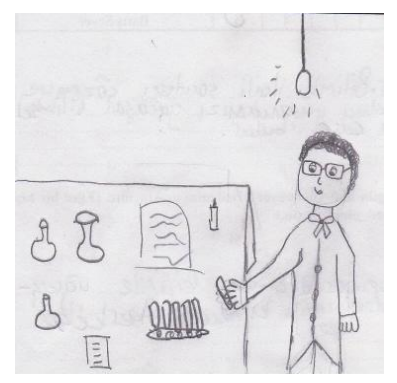

$7 \mathrm{M} 667$

Figure 2. The scientists' pictures drawn while experimenting

The places of the scientists drawn by the students are shown in Figure 3. Students drew scientists in a laboratory $(41.5 \%)$, at home $(14.4 \%)$, in an office $(7.4 \%)$, in a class $/$ school $(6.5 \%)$ and in the nature $(6 \%)$. Furthermore, a few students composed scientist pictures in a library, in a hospital, in an observatory, in space, in a pub, in a refectory, in bazaar, under the 
sod, at a police station, in a factory or inshore. Female students' average scores of laboratory, home, office and school/class are higher than male students' average scores. When compared to the students from the other grades, the $6^{\text {th }}$ grade students emphasized laboratory more but they emphasized nature less. The picture below is an example of the places where scientists' pictures were drawn.
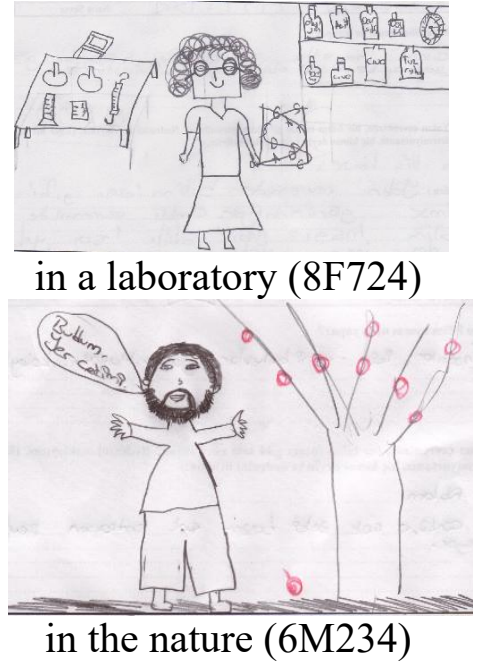

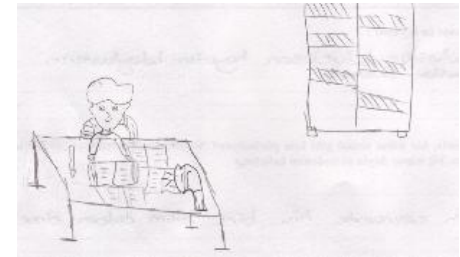

in an office (7F51)

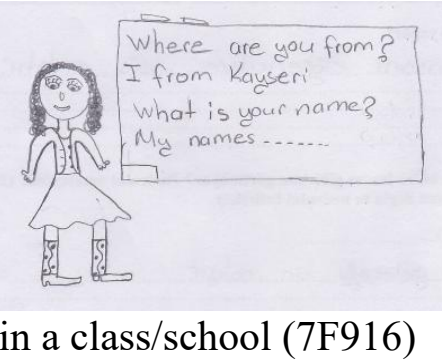

Figure 3. The place of the scientist

The most popular background features drawn by the students were "symbols of research" $(41.3 \%)$ and "symbols of knowledge" $(32.8 \%)$. For example, they indicated "laboratory material and equipment", "celestial bodies" and "writing-boards" etc. in background features. Female students specified symbols of research and symbols of knowledge more than the male students in their drawings. In addition, the $8^{\text {th }}$ grade students emphasized symbols of research and symbols of knowledge least. The students who emphasized the drawings of technology most were the $6^{\text {th }}$ graders. The following are some examples of the pictures drawn by the students (Figure 4).

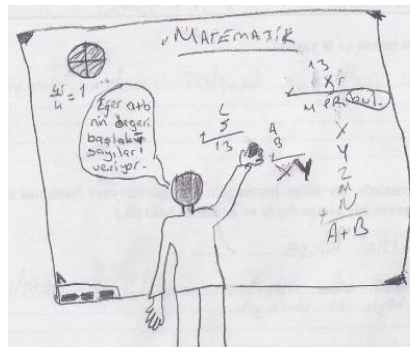

Symbols of knowledge (6F963)

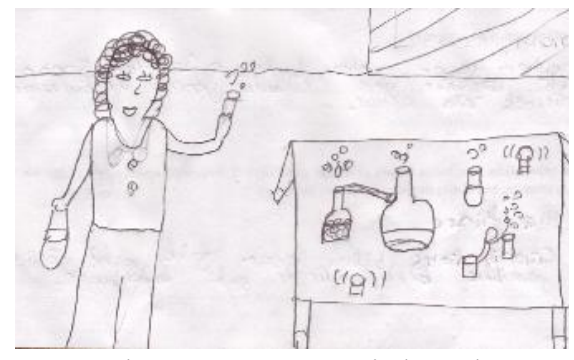

Laboratory material and equipment (7F48)

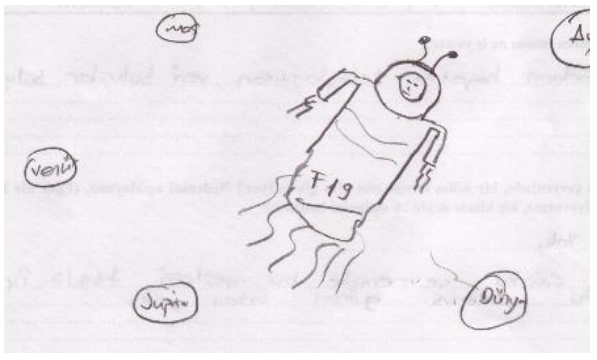

Celestial bodies (8M153)

Figure 4. The most popular background features

\section{Q3: The source of images of the scientist}

The distribution of students' responses belonging to the sources of their images of the scientists was presented in Table 8. 
Table 8. The sources of the images of the scientist (\%)

\begin{tabular}{lcccccc}
\hline & \multicolumn{2}{c}{ Gender } & \multicolumn{3}{c}{ Grades } & Total \\
\cline { 2 - 6 } & $\mathbf{M}$ & $\mathbf{F}$ & $\mathbf{6}^{\text {th }}$ & $\mathbf{7}^{\text {th }}$ & $\mathbf{8}^{\text {th }}$ & 49.3 \\
\hline Scientist's biographies & 48.1 & 50.3 & 47.1 & 49.1 & 51.8 & 43.9 \\
\hline Internet & 44.7 & 43.1 & 42.6 & 44.0 & 45.2 & 31.7 \\
\hline Textbooks & 31.0 & 32.3 & 29.8 & 31.9 & 33.5 & 30.7 \\
\hline Science Journals & 24.8 & 35.9 & 32.1 & 29.6 & 30.3 & 27.5 \\
\hline Films & 30.1 & 25.1 & 30.1 & 22.2 & 29.5 & 23.2 \\
\hline Teachers & 20.8 & 25.3 & 24.7 & 26.2 & 19.2 & 23.0 \\
\hline Newspapers & 22.7 & 23.2 & 17.0 & 24.5 & 27.7 & 20.2 \\
\hline Animated films & 25.0 & 15.9 & 22.7 & 15.5 & 22.3 & 17.8 \\
\hline Parents & 18.2 & 17.4 & 20.7 & 16.8 & 15.7 & 17.5 \\
\hline Museums & 16.1 & 18.7 & 20.7 & 17.5 & 14.3 & 15.6 \\
\hline Animated Cartoon Movies & 18.0 & 13.4 & 21.9 & 12.1 & 12.3 & 4.4 \\
\hline Cartoons & 3.6 & 5.1 & 6.5 & 3.7 & 2.9 & 0.07 \\
\hline Others & --- & 0.1 & 0.1 & --- & 0.1 & 5.1 \\
\hline No response & 6.6 & 3.8 & 4.3 & 5.4 & 5.7 & \\
\hline
\end{tabular}

In Q3, students were asked to name the sources of their images of the scientist. Table 8 shows that the most popular sources were scientist's biographies $(49.3 \%)$, the Internet $(43.9 \%)$, textbooks $(31.7 \%)$, science journals $(30.7 \%)$, films $(27.5 \%)$ and so on. There were some differences between female students' and male students' opinions. For instance, scientist's biographies, textbooks, teachers and science journals were more frequently selected by female students while films, animated films and cartoon films were more frequently chosen by male students. In other words, female students seem to encounter images of the scientist through more formal ways than male students. The comparison between different grade groups showed that $7^{\text {th }}$ grade students' mean scores were lower than the $6^{\text {th }}$ and $8^{\text {th }}$ grade students' in general.

\section{Q4: Scientists around us}

The distribution of the answers given by the students is shown in Table 9 .

Table 9. Scientists around us (\%)

\begin{tabular}{|c|c|c|c|c|c|c|c|}
\hline \multirow{2}{*}{$\begin{array}{l}\text { Scientists } \\
\text { around us }\end{array}$} & \multicolumn{2}{|c|}{ Gender } & \multicolumn{3}{|c|}{ Grades } & \multirow[b]{2}{*}{ Total } & \multirow[b]{2}{*}{ Quotations } \\
\hline & $\mathbf{M}$ & $\mathbf{F}$ & $6^{\text {th }}$ & $7^{\text {th }}$ & $8^{\text {th }}$ & & \\
\hline Nobody & 57.5 & 54.8 & 45.7 & 62.2 & 61.5 & 56.1 & $\begin{array}{l}\text { "Nobody because I do not see a person who is as intelligent, } \\
\text { creative, patient, hardworking, and careful as a scientist" } \\
\text { (8F274) } \\
\text { "Nobody because where we live is a small place. Scientists set } \\
\text { up their laboratories and work in developed cities and } \\
\text { countries" (6M641) } \\
\text { "Nobody because in my environment it does matter if it is a } \\
\text { female or male. They stop their education at the } 8^{\text {th }} \text { or } 12^{\text {th }} \\
\text { grades"( } 7 F 686) \\
\text { "Nobody. Everyone cares money; nobody works to make } \\
\text { contribution to humanity in this period" (8F279) } \\
\text { "Nobody because in my inner circle nobody thinks over such } \\
\text { things, everyone is preoccupied with their own problems" } \\
\text { (8F731) }\end{array}$ \\
\hline
\end{tabular}


Table 9 (continue). Scientists around us (\%)

\begin{tabular}{|c|c|c|c|c|c|c|c|c|c|}
\hline \multirow{2}{*}{\multicolumn{2}{|c|}{ Scientists around us }} & \multicolumn{3}{|c|}{ Gender } & \multicolumn{3}{|c|}{ Grades } & \multirow{2}{*}{ Total } & \multirow[t]{2}{*}{ Quotations } \\
\hline & & $\mathbf{M}$ & & & $6^{\text {th }}$ & $7^{\text {th }}$ & $8^{\text {th }}$ & & \\
\hline \multicolumn{2}{|l|}{ Teachers } & 14.2 & \multicolumn{2}{|c|}{18.9} & 19.9 & 16.8 & 13.4 & 16.7 & $\begin{array}{l}\text { "My science teacher because she teaches us } \\
\text { new subjects and does experiments" (8F257) } \\
\text { "My science and technology teacher because he } \\
\text { teaches us every information we have to learn } \\
\text { with experiments and I like that very much } \\
(8 F 715) \\
\text { "Teachers because thanks to teachers even } \\
\text { scientists became scientists by studying like us. } \\
\text { Their teachers taught them everything (6M25)" } \\
\text { "My teacher because scientists must have lost } \\
\text { their hair because of thinking. That's why } \\
\text { Mehmet teacher lost his hair (8M1000)", } \\
\text { "my teacher because he is wearing a white lab } \\
\text { coat and glasses (6M957)" }\end{array}$ \\
\hline \multicolumn{2}{|c|}{ Parents/Relatives ${ }^{1}$} & 8.5 & \multicolumn{2}{|c|}{14.0} & 15.1 & 11.1 & 8.0 & 11.4 & $\begin{array}{l}\text { "My father because he can find a solution to } \\
\text { anything in a minute. He made different tools } \\
\text { and he still uses them (6F552)";; } \\
\text { "My father because he can find a solution to } \\
\text { our problems (7F911)"; } \\
\text { "My elder brother. For example, he can make } \\
\text { something out of a radio or anything and he } \\
\text { spends a lot of time working on it (6F649)"; } \\
\text { "My uncle because he fulfils difficult tasks } \\
\text { which we can't do in the easiest way. He has } \\
\text { got creative ideas (7M672)"; } \\
\text { "My aunt because whatever I ask her, she } \\
\text { always answers me (6M245)"; } \\
\text { "My cousin. He gathered equipment and tools } \\
\text { and made a flying helicopter. In addition, he } \\
\text { reads a lot (6M633)"” }\end{array}$ \\
\hline Friends & 8.5 & 5.1 & 7.4 & 7.1 & 5.7 & & 6.7 & & $\begin{array}{l}\text { "My friend Başaran because he is very } \\
\text { intelligent, he reads a lot. He made perfect } \\
\text { things a few times (7M55)"; } \\
\text { "My friend Burak because he designs such } \\
\text { interesting projects that If I were a teacher, I } \\
\text { would grade him over } 100 \text { (6M625)"; } \\
\text { "My friend Cihan because he really looks like a } \\
\text { scientist (7M377)" }\end{array}$ \\
\hline Myself & 1.5 & 1.1 & 2.0 & 0.7 & 1.1 & & 1.3 & & $\begin{array}{l}\text { "I am because I am really curious and I like } \\
\text { inventing things. I believe that I have a strong } \\
\text { imagination (6F655)", } \\
\text { "I am because I have creative ideas. Lots of } \\
\text { things that can be made from different } \\
\text { equipment and tools come to my mind. I } \\
\text { constantly have the feeling that I want to do } \\
\text { things that will make people's life easy } \\
(7 F 574) "\end{array}$ \\
\hline Other $^{2}$ & 6.4 & 4.0 & 7.7 & 2.4 & 4.9 & & 5.1 & & $\begin{array}{l}\text { "Doctors because they treat people and also } \\
\text { they discover new medicines and vaccines with } \\
\text { their knowledge (7F800), } \\
\text { "My neighbour because his clothes and hair } \\
\text { resemble to a scientist (6M643)", } \\
\text { "My neighbour because he has got between } 10 \\
\text { and } 15 \text { inventions. Though only one of them } \\
\text { works, he is a very creative person (6M205)" }\end{array}$ \\
\hline & & & & & & & & & \\
\hline
\end{tabular}

${ }^{1}$ My father, my mother, my sister, my brother, my aunt, my uncle etc.

${ }^{2}$ My neighbour, film producer, person with glasses, doctors, vets, engineers etc.

When Table 9 is examined, $56.1 \%$ of the students answered that they could not think of anyone who could possibly be considered as the scientist. When students' general responses are examined, they think that there are not any scientists in their environment due to five 
different conditions: not individuals in students' environment who have cognitive skills of the scientists, the place where students live is small and it has got limited opportunities, the low education level of the individuals where they live, the importance of science is not known in the environment where they live and the individuals who live in their environment are not willing enough. Moreover, nearly $40 \%$ of the students stated that there were scientists in their environment. Teachers come first $(16.7 \%)$. Students stated that they regarded their teachers as scientists because they teach them new subjects, do experiments, and share the physical features of the scientists.

When students' views are examined, there are students (11.4\%) who see their families/relatives as a scientist. Students generally stated that they viewed their family members and relatives as a scientist because they invented different things, they generated creative solutions to problems, and they could answer all the questions. In addition to these, $6.7 \%$ of the students see their friends as a scientist. They expressed their opinions like that because their friends generally invented things, they were clever, hardworking, and creative like scientists, and they looked like scientists physically. In addition to this, $1.3 \%$ of the students see themselves as a scientist. $5.1 \%$ of the students said that they considered different people in their environment as a scientist.

When Table 9 is examined, female students and male students mostly consider their teachers, parents/relatives and friends as a scientist. As the students' grades increase, it is found that the students' views that there are not any scientists around them increase. Moreover, the higher the grades of students get, the less they see their friends, teachers, and relatives as scientist.

\section{Q5: My favourite scientist}

In Q5, students were asked to name a scientist whom they respected the most and to explain their reasoning in Table10.

Table 10. My favourite scientist (\%)

\begin{tabular}{|c|c|c|c|c|c|c|}
\hline \multirow[b]{2}{*}{ Favourite scientist } & \multicolumn{2}{|c|}{ Gender } & \multicolumn{3}{|c|}{ Grades } & \multirow[b]{2}{*}{ Total } \\
\hline & $\mathbf{M}$ & $\mathbf{F}$ & $6^{\text {th }}$ & $7^{\text {th }}$ & $8^{\text {th }}$ & \\
\hline Edison & 31.8 & 32.1 & 42.9 & 36.0 & 17.7 & 32.0 \\
\hline Einstein & 18.0 & 11.5 & 12.2 & 15.5 & 16.3 & 14.6 \\
\hline Graham Bell & 13.4 & 15.3 & 12.8 & 16.5 & 14.3 & 14.4 \\
\hline Newton & 4.2 & 6.0 & 5.4 & 5.4 & 4.9 & 5.2 \\
\hline Archimedes & 1.3 & 3.4 & 0.3 & 0.7 & 6.0 & 2.4 \\
\hline Ali Kuşçu & 2.1 & 0.9 & 0.3 & 0.3 & 3.7 & 1.5 \\
\hline Pasteur & 1.5 & 0.9 & 2.0 & 1.0 & 0.6 & 1.2 \\
\hline Dalton & 0.6 & 1.3 & 2.6 & 0.3 & --- & 1.0 \\
\hline Teachers & 7.6 & 8.3 & 9.1 & 9.1 & 6.0 & 8.0 \\
\hline Others $^{1}$ & 9.1 & 11.3 & 5.7 & 11.1 & 14.3 & 10.3 \\
\hline Nobody & 5.7 & 3.8 & 3.4 & 2.4 & 8.0 & 4.7 \\
\hline No response & 4.9 & 5.1 & 4.0 & 2.4 & 8.3 & 5.0 \\
\hline
\end{tabular}

${ }_{1}$ Galileo, Pascal, Democritus, Franklin, Mendel, Robert Hooke, Mendeleev, Volta, Leonardo Da Vinci, Atatürk, Mimar Sinan, Nicola Tesla, Henry Ford, Mary Crue, Ömer Hayyam, Thompson, Hezarfen Ahmet Çelebi, Kopernik and Neil Armstrong, Teachers, Doctors etc.

The most favourite scientists listed in Table 10 were Edison (32\%), Einstein (14.6\%), Graham Bell (14.4\%), teachers (8\%), Newton (5.2\%), Archimedes (2.4\%), Ali Kuşçu (1.5\%), Pasteur 
$(1.2 \%)$, and Dalton (1\%). One of the remarkable points is that the scientists named here were largely physicists. In addition to this, when students' views considering gender were examined, female students stated that their most favourite scientists were Edison, Graham Bell, Newton, Archimedes and Dalton and male students stated that their most favourite scientists were Einstein and Ali Kuşçu. Differences which draw attention in terms of grades is that Edison and teachers seen as a favourite scientist decrease as students' grades increase and Einstein and Bell increase as a favourite scientist as their grades increase. Moreover, "nobody" partially increases with the $8^{\text {th }}$ grade students when compared to other grades.

When the study was carried out, another thing which drew attention from the students' responses is that scientists' names were misspelled. Table 11 presents the names misspelled and their distribution.

Table 11. Scientists whose names misspelled (\%)

\begin{tabular}{ccccccc}
\hline \multirow{2}{*}{ Favourite scientist } & \multicolumn{2}{c}{ Gender } & \multicolumn{3}{c}{ Grades } & Total \\
\cline { 2 - 6 } Einstein & $\mathbf{M}$ & $\mathbf{F}$ & $\mathbf{6}^{\text {th }}$ & $\mathbf{7}^{\text {th }}$ & $\mathbf{8}^{\text {th }}$ & 6.1 \\
\hline Graham Bell & 8.7 & 3.8 & 4.5 & 6.7 & 8.6 & 5.5 \\
\hline Archimedes & 6.1 & 4.9 & 6.2 & 5.7 & 4.6 & 1.5 \\
\hline Edison & 1.1 & 1.9 & --- & 0.3 & 4.0 & 1.1 \\
\hline Newton & 1.5 & 0.6 & 1.1 & 1.3 & 0.9 & 1.0 \\
\hline Pasteur & 1.5 & 0.6 & 0.6 & 1.7 & 0.9 & 1.0 \\
\hline Others ${ }^{1}$ & 1.5 & 0.6 & 1.7 & 1.3 & --- & 2.5 \\
\hline Total & 2.1 & 2.8 & 2.3 & 2.7 & 2.6 & 19.4 \\
\hline
\end{tabular}

${ }^{1}$ Galileo, Mary Curie, Democritus, Thompson, Dalton, Volta.

When Table 11 is examined, it is found that more than two-thirds of the students spelled scientists' names correctly but one-fifth of them misspelled them. The scientist whose name was mostly misspelled was Einstein (6.1\%) and then Graham Bell (5.5\%). Archimedes (1.5\%), Edison (1.1\%), Newton (1.0\%) and Pasteur (1.0\%) follow him. Another important thing about spelling of scientists' names is that female students were more successful than the male students. Moreover, another important finding regarding grades is that the most successful grade was the $6^{\text {th }}$ grade. To exemplify the false names given by the students, students called Einstein as "Einştan, Einastian, Einsteen, Eintensi, Ajdaym, Ainsthan, Açtan, Ajtahan etc.", Graham Bell as "Granbel, Grawben, Grember, Gran beel, Gradhammen, Grandbel etc.", and Edison "Edinos, Edilsom, Edision, Edisyan etc." and Newton as "Nivton, Nilton, Ewton etc." In Q5, students were asked why they were impressed with the scientists whose names they gave and the results were presented in Table 12. 
Table 12. Being impressed from the scientists (\%)

\begin{tabular}{|c|c|c|c|c|c|c|c|}
\hline \multirow{2}{*}{$\begin{array}{l}\text { Reason for respecting the } \\
\text { scientist }\end{array}$} & \multicolumn{2}{|c|}{ Gender } & \multicolumn{3}{|c|}{ Grades } & \multirow[b]{2}{*}{ Total } & \multirow[b]{2}{*}{ Quotations } \\
\hline & $\mathbf{M}$ & $\mathbf{F}$ & $6^{\text {th }}$ & $7^{\text {th }}$ & $8^{\text {th }}$ & & \\
\hline Achievements & 54.1 & 58.0 & 58.8 & 62.2 & 48.6 & 56.2 & $\begin{array}{l}\text { "If Graham Bell had not } \\
\text { invented that telephone; we } \\
\text { would not be talking to our } \\
\text { relatives away from us now. We } \\
\text { would not go there on time on } \\
\text { the condition that there is a } \\
\text { funeral or a very important } \\
\text { work. That's why I respect him a } \\
\text { lot (8M251)"; } \\
\text { "Edison because he invented the } \\
\text { light bulb. He illuminated our } \\
\text { world. Thanks to him, we can do } \\
\text { our homework (7F101)", }\end{array}$ \\
\hline For their life story & 6.1 & 7.2 & 6.2 & 8.4 & 5.7 & 6.7 & $\begin{array}{l}\text { "Einstein because I was very } \\
\text { much impressed with the fact } \\
\text { that he did not like school. The } \\
\text { fact that he did not like school } \\
\text { did not prevent him from being a } \\
\text { scientist (8F396)" }\end{array}$ \\
\hline Personal characteristics & & & & & & 16.0 & \\
\hline Cognitive aspects & 17.0 & 12.9 & 14.8 & 12.4 & 17.4 & 14.8 & "Edison because he tried to \\
\hline Intelligent & 9.1 & 5.3 & 6.0 & 5.7 & 9.4 & 7.1 & $\begin{array}{l}\text { invent the light bulb } 1000 \text { times } \\
\text { and he eventually succeeded. }\end{array}$ \\
\hline Creative & 3.0 & 2.1 & 3.1 & 2.0 & 2.3 & 2.5 & That he was so determined \\
\hline Resolute & 4.5 & 5.7 & 6.0 & 4.0 & 5.1 & 5.1 & attracted my attention (8F 392) \\
\hline Humanistic & 0.6 & 0.2 & --- & 0.7 & 0.6 & 0.4 & \\
\hline Physical aspects & 1.1 & 1.3 & 0.3 & 1.7 & 1.7 & 1.2 & $\begin{array}{l}\text { "Einstein because I saw him } \\
\text { sticking out his tongue in one of } \\
\text { his photos and I wanted to read } \\
\text { his book. I was curious about } \\
\text { him (7F577)" }\end{array}$ \\
\hline Others & 11.4 & 11.5 & 12.5 & 10.8 & 11.2 & 11.5 & $\begin{array}{l}\text { "Edison because I frequently } \\
\text { encountered his name in the } \\
\text { books and the journals } \\
\text { (6F747)", } \\
\text { "Einstein because I mostly see } \\
\text { him in the course books } \\
(8 F 295) " \text { " }\end{array}$ \\
\hline Nobody & 5.5 & 4.0 & 3.4 & 2.7 & 7.7 & 4.7 & \\
\hline No response & 5.1 & 4.9 & 3.7 & 2.7 & 8.3 & 5.0 & \\
\hline
\end{tabular}

Table 12 shows that the students' reasons for respecting the scientists were grouped under achievements of the scientists, the life story of the scientists and the personal characteristics of the scientists. It is found that nearly more than half of the students $(56.2 \%)$ were impressed with the achievements of the scientists. Scientists' personal characteristics (14.8\%) [cognitive aspects $(14.8 \%)$ and physical aspects $(1.2 \%)]$, and life stories (6.7\%) respectively. Mainly 8th grade students and then nearly $10 \%$ of the students did not answer this question or they gave the response "nobody". Apart from these, there are some students who mentioned different reasons.

\section{Q6. Being a Scientist}

In Q6, students were asked whether they wanted to be a scientist or not and the results were presented in Table 13. . 
Table 13. Students who want to be a scientist or not (\%).

\begin{tabular}{lccccccc}
\hline \multirow{2}{*}{ Answers } & \multicolumn{2}{c}{ Gender } & \multicolumn{3}{c}{ Grades } & \multirow{2}{*}{ Total } \\
\cline { 2 - 6 } Yes & $\mathbf{M}$ & $\mathbf{F}$ & $\mathbf{6}^{\text {th }}$ & $\mathbf{7}^{\text {th }}$ & $\mathbf{8}^{\text {th }}$ & 69.0 \\
\hline No & 68.9 & 69.0 & 74.4 & 70.9 & 62.1 & 16.5 \\
\hline No Response & 15.3 & 17.6 & 13.1 & 18.1 & 18.6 & 14.5 \\
\hline
\end{tabular}

When Table 13 is examined, it is revealed that generally more than two-thirds of the students wanted to be a scientist. Moreover, it is found that female students and the $6^{\text {th }}$ grade students wanted to be a scientist more than the male students and the other students in upper grades. The views of the students who want to be a scientist / who don't want to be a scientist were given in Table 14.

Table 14. Reasons for wanting to be a scientist or not (\%)

\begin{tabular}{|c|c|c|c|}
\hline & Reason & Total & Quotations \\
\hline \multirow[t]{4}{*}{ ભิ } & $\begin{array}{l}\text { To make inventions/discoveries } \\
\text { (In physics, medicine, education and etc fields) }\end{array}$ & 40.8 & $\begin{array}{l}\text { "For example, I would like to invent a cooker which } \\
\text { turns itself off after the meal is cooked so that it does } \\
\text { not burn. So, our mothers don' } t \text { have to check } \\
\text { whether the food is cooked or not all the time } \\
\text { (7M674)", } \\
\text { "... I can make an iron which irons the clothes by } \\
\text { itself. So, my mother has more time for herself. For } \\
\text { example, while my mum is washing the dishes, the } \\
\text { iron can iron the clothes (6M636)"; } \\
\text { “... I can make a talking map for students. When I } \\
\text { tell it to show me the features of a place, it will show } \\
\text { me and begin to explain it to me (8M780)”, } \\
\text { "... I will design a medicine machine which makes } \\
\text { pills automatically for patients and the elderly } \\
\text { (6F653)". }\end{array}$ \\
\hline & $\begin{array}{l}\text { To do research in different science branches } \\
\text { (Medicine /environment }(7.4 \%) \text {, Physics } \\
(4.4 \%) \text {, Computer/Electronics }(2 \%) \text {, Biology } \\
(1.5 \%) \text {, Chemistry (1\%) etc.) }\end{array}$ & 17.0 & $\begin{array}{l}\text { "Yes, I will find medicine for the illnesses which do } \\
\text { not have a medication (6F887)" } \\
\text { "I would. I can carry out studies on space sciences } \\
\text { (7M566) }\end{array}$ \\
\hline & To be famous & 2.9 & $\begin{array}{l}\text { "Of course I would. My name will appear in the } \\
\text { textbooks, everyone will search my life. This is a great } \\
\text { thing (8F274) }\end{array}$ \\
\hline & $\begin{array}{l}\text { Other(s) } \\
\text { (To be useful for the society, for education, and } \\
\text { for the development of the country) }\end{array}$ & 8.6 & $\begin{array}{l}\text { "Yes, I would like to prevent earthquake. Thousands } \\
\text { of people die due to an earthquake. Do not let people } \\
\text { die (8M1000)" } \\
\text { "Yes, because I want my country to be a better place } \\
\text { in the future and more developed ( } 6 F 965)\end{array}$ \\
\hline \multirow{4}{*}{$\begin{array}{l}0 \\
Z\end{array}$} & $\begin{array}{l}\text { Due to my personal preferences } \\
\text { (Because I am not interested (5\%), because I } \\
\text { chose another profession, (3\%), because I don't } \\
\text { want to work hard ( } 1.5 \%) \text { and etc) } \\
\end{array}$ & 8.6 & $\begin{array}{l}\text { "No, I don't want to be a scientist because I want to } \\
\text { be a nurse (6F761)" } \\
\text { "No, because I'm not used to making innovations } \\
\text { and dreaming (7F799)", }\end{array}$ \\
\hline & $\begin{array}{l}\text { Due to the scientists' features/missions } \\
\text { (Because of its responsibilities }(2 \%) \text {, because } \\
\text { they invented bad things, }(1.4 \%) \text {, because it is } \\
\text { boring }(1.2 \%) \text { etc.) }\end{array}$ & 4.7 & $\begin{array}{l}\text { "No, because it is a very difficult job. Because I like } \\
\text { fun, I can't devote my entire life just for an invention } \\
\text { (8F712)" }\end{array}$ \\
\hline & $\begin{array}{l}\text { Due to their personal characteristics } \\
\text { (Because I am not smart, }(1.6 \%) \text {, because I get } \\
\text { bored easily }(0.6 \%) \text {, because I am not creative } \\
(0.4), \text { because I am not careful }(0.3 \%) \text { and etc.) }\end{array}$ & 3.0 & $\begin{array}{l}\text { "Scientists are intelligent. I am not that clever. If I } \\
\text { were a scientist, I wouldn't do anything (6M7)", }\end{array}$ \\
\hline & No response & 15.0 & \\
\hline
\end{tabular}

When Table 14 is examined, it is revealed that the reasons for wanting to be a scientist were listed: $40.8 \%$ of the students wanted to make inventions/discoveries, $17 \%$ of them wanted to do research in different science branches, and 3\% of them wanted to become famous. Nearly half of the students who wanted to be a scientist stated that they wanted to make different 
inventions. When the students' responses who want to be a scientist to do research in different science branches are examined, it shows distribution in these fields: Medicine/Environment (7.4\%), Physics/Astronomy (4.4\%), Computer/Electronics (2\%), Biology (1.5\%), Chemistry $(1 \%)$ and etc. In addition to these, there are students who want to be a scientist to be famous. $8.6 \%$ of the students stated that they wanted to become a scientist for being useful for the society, education and the development of their country. $15 \%$ of the students did not answer this question. However, it is found that $16.3 \%$ of the students did not want to be a scientist due to several reasons (such as individual preferences/ features, scientists' features and duties).

\section{Discussions, Conclusions and Recommendations}

This study aimed at in-depth examination of middle school students' images of scientists. Because it was found out the previous studies which conducted in different education levels and in different countries that the participant's images of the scientists revealed similar results to the findings of the pioneering studies carried out by Mead and Metraux (1957) and Chambers (1983), a belief that there were stereotypic images of the scientist were prevalent (Akcay, 2011; Buldu, 2006; Buluş-Kırıkkaya, et al. 2011; Camc1Erdoğan, 2013a, 2013b; Fralick, et al, 2009; Fung, 2002; Huber, \& Burton, 1995; Kaya et. al. 2008; Kibar-Kavak, 2008; Korkmaz, \& Kavak, 2010; Medina-Jerez, et al, 2011; Monhardt, 2003; Nuhoğlu \& Afacan, 2011; Song, \& Kim, 1999; Öcal, 2007; She, 1995; Türkmen, 2008; Ünver, 2010; Yontar-Toğrol, 2013). Thus, the studies (Bowtell, 1996; Barman, 1999; Koren \& Bar, 2009; Monhardt, 2003; Song \& Kim, 1999; Ünver, 2010) which tried to determine participants' images of the scientist revealed that the participants' images of the scientist were stereotypical. It was observed that the participants' stereotypic images of the scientist have existed without changing for years (Chambers, 1983; Losh, Wilke \& Pop, 2008; Song \& Kim, 1999; Silver \& Rushton, 2008). Similarly, when they were compared regarding differences like gender and grades, it was found that $6^{\text {th }}, 7^{\text {th }}$ and $8^{\text {th }}$ grade pupils had similar perceptions and even there was a decrease in their images of the scientist' scores. It was revealed in literature that pupil's images of the scientist did not change throughout their education (Huber \& Burton, 1995; Hatzinikita, 2007; Kaya et al, 2008, Türkmen, 2008).

The findings revealed that regarding mental images of the scientist, scientist had positive features such as intelligent, accurate, industrious and imaginative but they had also negative images like boring, religious and artistic in students' minds. There are positive (Akinoglu, Tatik \& Baykin, 2015; Song \& Kim, 1999) and negative (McDuffie, 2001; Rubin, Bar \& Cohen, 2003; Parsons, 1997) students' images/perceptions of the scientist existing in literature.

Among the mental images of the scientist' features, it was found that students generally thought that scientists were not religious. When students' reasons were examined (Table 5), it was revealed that although students stated that the relation between science and religion were independent of each other, their opinion "they are not very religious" displayed their uncertainty. In addition to this, the Muslim students' opinions like being not Muslim and not believing in God display that they have significant gap in knowledge about religion and science. It is considered that students' such ideas were generated via informal ways. Pedagogues and philosophers should conduct studies collaboratively about the emergence and production processes of science, philosophy, art, and religion as disciplines, so the studies which will compose teachers' theoretical substructure are required to prevent such beliefs, to understand the nature of science, and to distinguish science-pseudo science (Turgut, 2009). 
Thus, it is thought that students' misconceptions or wrong beliefs towards scientist can be eliminated.

It is observed that students had positive views when they evaluated themselves considering mental images of the scientist. These views show parallelism with their opinions of the scientist. So, the correlation coefficient between these two features reveals quite a high and positive relation. It can be concluded with this situation that while describing students' images of the scientist which were affected with their attitudes and perceptions, they created an image thinking themselves as a scientist. In contrast, the findings reveal that $69 \%$ of the students stated that they wanted to be a scientist (in Table 13 ), however, only $1.3 \%$ of them thought themselves as a scientist (in Table 9). The students who participated in the study stated that the main reason why they were so willing to become a scientist was to make inventions and discoveries in different fields.

Regarding the physical features of the scientist, students generally described a scientist as man in his 30s with strange hair style and an ordinary look, wearing glasses, beard/moustache, and a lab coat. Students' images of the scientist in this study showed the similarities with the images of the scientist revealed in the studies carried out in different ages, cultures and societies in the world (Ağgül-Yalçın, 2012; Barman, 1999; BuluşKirlkkaya, et al, 2011; Chambers 1983; Finson, 2002; Finson, Pedersen, \& Thomas, 2006; Finson, Beaver \& Cramond, 1995; Fung, 2002; Huber \& Burton 1995; Kaya, et al, 2008; Korkmaz \& Kavak, 2010; Moseley \& Norris, 1999; Özsoy \& Ahi, 2014; Rosenthal, 1993; Schibeci \& Sorensen, 1983; Song \& Kim, 1999; Symington \& Spurling, 1990; Türkmen, 2008; Ünver, 2010). Few students in this study mentioned that scientists were bald. On the other hand, this ratio is quite high in literature. Students generally drew male scientist (BuluşKırıkkaya, et al, 2011; Erkorkmaz, 2009; Öcal, 2007; Song \& Kim, 1999; Şen-Gümüş, 2009; Ünver, 2010). This case may result from our native language (Turkish). In the Turkish language the word "scientist" means "science man". Thus, it may explain the stereotypical image of male scientist in the drawings of Turkish students. For this reason, in Turkey, teachers should try to use the term of "science person" instead of "scientist" while teaching science (Akcay, 2011). Another example to this condition can be explained with the statement of a student in the study carried out by Ünver (2010): "I cannot be a scientist because I am not a man, I am a girl". While some studies reveal that no male students drew female scientists (Buldu, 2006; Gunsolin, 2001), it is found in this study that very few male students drew female scientists. This result shows that misperception about the scientist's gender have been encountered in the studies carried out in the other countries (Barman, 1999; Farland-Smith, 2009). Among the suggestions which can be made regarding this result, what comes frequently in mind is that students can spend time in science camps and they can change their images of the scientist. Thus, Leblebicioglu, Metin, Yardimci and Cetin, (2011) demonstrated that joining a science camp can affect students' images of the scientist by introducing scientists with their personal life and humane character (affective) in addition to their scientific skills and scientific studies (cognitive). Crowther, Norman and Lederman, (2005) suggested that teachers should design and develop learning environments with activities and projects for their students so that they can understand and comprehend science and nature of science. These situations show that "stereotypical images" of the scientist can be got rid of students' mind with correct steps in the right direction.

Another important finding in parallel with the studies in literature (Buldu, 2006; Camc1Erdoğan, 2013b) is that female students generally drew female scientist. Such expressions about a scientist like "a person who knows everything", or "lots of things", "a man who invents or discovers things" were encountered in the study and gender roles were also mentioned in these expressions. As stated by Korkmaz and Kavak (2010), the students must 
be introduced to the idea that carrying out scientific study does not depend on a specific age, gender and physical features and everyone can conduct a study on any scientific topic.

With regard to activity of the scientist, students stated that scientists were interested in invention, research and experiment. Similarly, in the study conducted by Song and Kim (1999) "research", "experiment" and "invention" were in the top three list. In addition to this, in the studies conducted by Güler and Akman (2006), students stated that scientists worked hard, went to work and earned money.

Students generally determined that the place of the scientist was laboratory. As in this study, few primary students drew scientists in nature or space (Özsoy \& Ahi, 2014). Students revealed with these drawings that scientific studies could only be conducted indoors like a laboratory. But, in order to emphasize that scientists can work not only in laboratory but also in everywhere, various class and outdoor activities such as trips, observations, investigations and researches should be carried out (Korkmaz \& Kavak, 2010). The main reason might be that scientists were shown in the textbooks and mass media while they are working in a laboratory with their "experiment tubes, chemicals, and laboratory equipment and tools" (Ăggül-Yalçın, 2012; Buldu, 2006; Buluş-Kırıkkaya, et al, 2011; Camcı-Erdoğan, 2013a, 2013b; Güler \& Akman, 2006; Korkmaz \& Kavak, 2010; Ortoli \& Witkowski, 2006; Özsoy \& Ahi, 2014; Schibeci, 1986; Song \& Kim, 1999; Türkmen, 2008; Yontar-Toğrol, 2000).

Background features of the pictures generally present symbols of research and knowledge. These explanations are similar to the studies in literature (Buldu, 2006; Chambers, 1983; Finson, et al, 1995; Leblebicioglu, et al, 2011; Newton \& Newton, 1992; Özsoy \& Ahi, 2014; Türkmen, 2008).

For the source of the images of the scientist, students generally listed scientists' life stories, the Internet, course books, science journals, and films. Particularly male students stated that they got information from their life stories, the Internet, and animated films and female students mentioned that they got information from life stories, the Internet, course books, science journals, teachers and museums. According to Jones et al (2000) students' views of the scientist mostly depend on the messages received from out of school settings. That's why it is frequently emphasized in educational reports (NAE \& NRC, 2009; NGSS, 2013) that learning environments should be designed considering scientific process so that correct images of the scientists can be created within students and prospective scientists can be raised. Therefore, although these myths constantly create curiosity within students, they cannot change the fact that the limited image of the scientist in their perceptions must change.

Students stated that there were not any scientists around them (Camc1-Erdoğan, 2013a; BuluşKirikkaya, et al, 2011; Song \& Kim, 1999). Ünver (2010) stated that most of the university students in their last years mentioned that although they were at university, they did not meet any scientists. The students who participated in this study listed their favourite scientists as Edison, Einstein and Graham Bell. Similarly, Edison and Einstein take place on the top in literature (Ağgül-Yalçın, 2012; Buluş-Kırıkkaya, et al, 2011; Korkmaz \& Kavak, 2010; Song \& Kim, 1999; Türkmen, 2008). Karaçam, et al, (2015) in their study determined that the names of the scientists occurred least in the $5^{\text {th }}$ grade science course books and most in the $8^{\text {th }}$ grade science course books. In addition to this, although some of the scientists' names did not exist in the course books, it is interesting that they were expressed by the students. However, it is found that although students did not mention that many scientists included in the course books, they frequently mentioned Einstein and Newton. This result supports the finding by Jones et al. (2000) who stated that ideas of the scientist were obtained from sources out of school settings. Moreover, it can be considered that students gave examples from the 
scientists who had myths (Ortoli \& Witcowski, 2006): To exemplify, while Euclid and Pythagoras who explained the buoyancy of water were not known a lot by the people, Archimedes was recognized more. It is stated that the reason for this condition may have resulted from the "Eureka" myth or story which was not explained clearly or fully. Moreover, another example for this situation is that Newton's apple which was responsible for the discovery of gravity was known more than the gravity.

Some students stated people like teacher as their favourite scientist in the study. Some studies in the literature revealed that scientists worked as a doctor, professor, and teacher (Güler \& Akman, 2006; Newton \& Newton; 1992). In addition, there is an important point that female scientists like Marie Curie were not specified. The studies in the literature reveal that especially female students considered female scientists like Marie Curie as their favourite scientist (Camc1-Erdoğan, 2013b; Korkmaz \& Kavak, 2010; Song \& Kim, 1999). Moreover, it was found that while students mentioned their favourite scientists, they misspelled their names. Einstein and Graham Bell are among the scientists whose names were misspelled. It is considered that students misspelled them because they were foreign names and they were not suitable to the Turkish language structure.

Students generally stated that they were impressed with the achievements of the scientists. It was found by the studies in literature that participants respected scientists due to their achievements and contribution they made to humanity (Ağgül-Yalçın, 2012; Camc1-Erdoğan, 2013a; Song \& Kim, 1999). In addition to that Akinoglu, Tatik and Baykin (2015) found that pre-service teachers described scientists as individuals who are knowledgeable, creative, cultured, curious, and making contributions to society. It was found in the study that students were impressed with the different features of different scientists. It was determined that students especially were impressed with Edison's life story and determination, Einstein's life story and physical appearance, Graham Bell's achievements and intelligence and Newton's achievements. In addition to that, students respected scientists' cognitive aspects as well as their intelligence as suggested by Korkmaz and Kavak (2010) in their study. When the responses to this question were examined, some misconceptions occurred. The most common misconception expressed by the students is that Edison invented electricity in place of light bulb. In addition to this, considering some students' views, they stated that everything would fly on condition that Newton had not discovered the law of gravity.

The studies which were conducted on students' images of the scientist reveal that their perceptions and cognitive images towards scientists have an important effect on their attitudes towards science and their career choices in the future (Finson, 2002; Kahle, 1989; Schibeci, 1986). Thus, it is emphasised that science course books should be designed with such a content that it will make contributions to students' images of science and the scientist (She, 1995) and scientists' positive features like curious, hardworking, and determined should be introduced so students can have a positive image (Ağgül-Yalçın, 2012; Türkmen, 2008). Moreover, studies and life stories of scientists from different disciplines must be given more coverage in media, on the Internet, and in the course books so students can create a positive image (Ağgül - Yalçın, 2012; Finson, 2002; Korkmaz \& Kavak, 2010). Within this framework, it is thought that the number of scientists, from different cultures and disciplines, and had a life story should be increased in the course books.

\section{References}

Ağgül-Yalçın, F. (2012). Investigation of prospective teachers' image of scientist with respect to some variables. Elementary Education Online, 11(3), 611-628. 
Akcay, B. (2011). Turkish elementary and secondary students' views about science and scientist. Asia-Pacific Forum on Science Learning and Teaching, 12(1), 1-11.

Akinoglu, O., Tatik, R.S., \& Baykin, Y. (2015). Pre-service teachers' metaphorical perceptions towards the concept of scientist. Anthropologist, 19(3), 577-584.

Barman, C.R. (1999). Completing the study: High school students' views of scientists and science. Science and Children, 36(7), 16-21.

Bowtell, E. (1996). Educational stereotyping: Children's perceptions of scientists: 1990's style. Investigating: Australian Primary and Junior Science Journal, 12 (1), 104- 108.

Buldu, M. (2006). Young children's perceptions of scientists: a preliminary study. Educational Research, 48(1), 121-132.

Buluş-Kırıkkaya, E., Bozkurt E., \& İşeri, Ş. (2011). TÜBİTAK destekli ilköğretim öğrencileri Bilim Yaz Okulu'nun öğrencileirn bilim insanı imgelerine etkisi. Mediterranean Journal of Educational Research, 5(9), 61-75.

Camc1-Erdoğan, S. (2013a). Gifted and talented students' images of scientists. Turkish Journal of Giftedness and Education, 3(1), 13-37.

Camc1-Erdoğan, S. (2013b). Üstün zekâlı kızların bilime yönelik tutumları ve bilim insanı imajlar1. HAYEF: Journal of Education, 10(1), 125-142.

Chambers, D.W. (1983). Stereotypic images of the scientist: The draw - a - scientist test. Science Education, 67(2), 255-265.

Cohen, L., Manion, L., \& Morrison, K. (2000). Research in education. London: Routledge Falmer.

Crowther, D.T., Norman, G.L., \& Lederman, J.S. (2005). Understanding the true meaning of nature of science. Science and Children, 43(2), 50-52.

Erkorkmaz, Z. (2009). İlköğretim 1. kademe öğrencilerinin bilim insanına ilişkin görüşlerinin belirlenmesi [Determining the opinions of the first level elementary students about the scientist]. (Unpublished master thesis). Süleyman Demirel University, Isparta, Turkey.

Farland-Smith, D. (2009). How does culture shape students' perceptions of scientists? Crossnational comparative study of American and Chinese elementary students. Journal of Elementary Science Education, 21(4), 23-42.

Finson, K.D., Beaver, J. B., \& Cramond, B.L. (1995). Development and field test of a checklist for the Draw-a-Scientist Test. School Science and Mathematics, 95(4), 195 205.

Finson, K.D. (2002). Drawing a scientist: What we do and do not know after fifty years of drawings. School Science and Mathematics, 102(7), 335-345.

Finson, K.D., Pedersen, J., \& Thomas, J. (2006). Comparing science teaching styles to students' perceptions of scientists. School Science and Mathematics, 106(1), 8-15.

Fralick, B., Kearn, J., Thompson, S., \& Lyons, J. (2009). How middle schoolers draw engineers and scientists. Journal of Science Education \& Technology, 18(1), 60-73.

Fung, Y.Y.H. (2002). A comparative study of primary and secondary school students' images of scientists. Research in Science \& Technological Education, 20(2), 199-213.

Gonsoulin, W.B. (2001). How do middle school students depict science and scientist. (Doctoral Thesis). Mississippi State University, USA.

Gormally, C., Brickman, P., Hallar, B., \& Armstrong, N. (2009). Effects of inquiry-based learning on students' science literacy skills and confidence. International Journal for the Scholarship of Teaching and Learning, 3 (2), Article16. Retrieved from $\mathrm{http}$ ://digitalcommons.georgiasouthern.edu/cgi/viewcontent.cgi? article=1182\&context= ij-sotl

Güler, T. \& Akman, B. (2006). 6 yaş çocuklarının bilim ve bilim insanı hakkındaki görüşleri [6 Years old childrens' views on science and scientists]. Hacettepe University Journal of Education, 31, 55-66. 
Hatzinikita, V. (2007). Images of the scientist held by educator in Greece. The International Journal of Learning, 14(7), 145-154.

Huber, R.A. \& Burton, G.M. (1995). What do students think scientists look like? School Science and Mathematics, 95(7), 371-376.

Jones, M. G., Howe, A., \& Rua, M. J. (2000). Gender differences in students' experiences, interests, and attitudes toward science and scientists. Science Education, 84(2), 180-192.

Kahle, J. B. (1989). Images of scientists: Gender issues in science classrooms. The Key Centre for School Science and Mathematics, 4, 1-9.

Karaçam, S., Aydın, F., \& Digilli, A. (2014). Fen ders kitaplarında sunulan bilim insanlarının basmakalıp bilim insani imaji açısından değerlendirilmesi [Evaluation of scientists represented in science textbooks in terms of stereotype scientist image]. Ondokuz Mayis University Journal of Education Faculty, 33(2), 606-627.

Kaya, O.N., Doğan, A. \& Öcal, E. (2008). Turkish elementary school students' images of scientists. Eurasian Journal of Educational Research, 32, 83-100.

Kibar-Kavak, G. (2008). Ögrencilerin bilime ve bilim insanına yönelik tutumlarını ve imajlarını etkileyen faktörler [Factors affecting the attitudes and perception of the students towards science and scientists]. (Unpublished master thesis). Selçuk University, Konya, Turkey.

Koren, P. \& Bar, V. (2009). Science and It's Images - Promise and threat: from classic literature to contemporary students' images of science and "The Scientist". Interchange, 40(2), 141-163.

Korkmaz, H. \& Kavak, G. (2010). Primary school students' images of science and scientists. Elementary Education Online, 9(3), 1055-1079.

Leblebicioglu, G., Metin, D., Yardimci, E., \& Cetin, P. S. (2011). The effect of informal and formal interaction between scientists and children at a science camp on their images of scientists. Science Education International, 22(3), 158-174.

Losh, S. C.,Wilke, R. \& Pop, M. (2008). Some methodological issues with "Draw a Scientist Tests" among young children. International Journal of Science Education, 30(6), 773792.

McDuffie, T.E.J. (2001). "Scientists-Geeks and Nerds?" dispelling teachers' stereotypes of scientists. Science and Children, 38(8),16-19.

MNE (Ministery of National Education) [Milli Eğitim Bakanlığg], (2013). Fen bilimleri dersi program1, 3.-8. siniflar [Science course curriculum, 3-8 classes]. Retrieved from http://tkb.meb.gov.tr/www/guncellenen-ogretim-programlari/icerik/151.

Medina-Jerez, W., Middleton, K.V., \& Orihuela-Rabaza, W. (2011). Using the DAST-C to explore Colombian and Bolivian students' images of scientists. International Journal of Science and Mathematics Education, 9(3), 657-690.

Monhardt, R.M. (2003). The image of the scientist through the eyes of Navajo children. Journal of American Indian Education, 42(3), 25-39.

Moseley, C. \& Norris, D. (1999). Pre-service teachers' views of scientists. Science and Children, 37(1), 50-53.

NAE [National Academy of Engineering] \& NRC [National Research Council]. (2009). Engineering in K-12 education understanding the status and improving the prospects. Edt. Katehi, L., Pearson, G. \& Feder, M. Washington, DC: National Academies Press.

Newton, D.P. \& Newton, L.D. (1992). Young children's perceptions of science and the scientist. International Journal of Science Education, 14(3), 331-348.

NGSS [New Generation Science Standards] (2013). Retrieved from http://www.nextgenscience.org

Nuhoğlu, H. \& Afacan, Ö. (2011). İlköğretim öğrencilerinin bilim insanına yönelik düşüncelerinin değerlendirilmesi [Evaluation of the primary school students' view about scientists]. Ahi Evran Üniversitesi Kırşehir Ĕ̈itim Fakültesi Dergisi, 12(3). 279-298. 
Ortoli, S. \& Witkowski, N. (2006). Arşimet'in hamamı: Bir bilim söylenceleri kitapçığı. [Archimedes' bath: A science of myths]. İstanbul: Yap1 Kredi Publishing.

Öcal, E. (2007). Illkögretim 6, 7 ve 8. sinıf ögrencilerinin bilim insanı hakkındaki imaj ve görüşlerinin belirlenmesi [Identification and description of 6,7,8. secondary school student's scientist image and schema]. (Unpublished master thesis). Gazi University, Ankara, Turkey.

Özsoy, S. \& Ahi, B. (2014). Images of scientists through the eyes of the children. Necatibey Faculty of Education Electronic Journal of Science \& Mathematics Education, 8(1), 204-230

Parsons, E.C. (1997). Black high school females' images of the scientist: Expression of culture. Journal of Research in Science Teaching, 34 (7), 745-768.

Rosenthal, D.B. (1993). Images of scientists: A comparison of biology and liberal studies majors. School Science and Mathematics, 93, 212-216.

Rubin, E., Bar, V. \& Cohen, A. (2003). The images of scientists and science among Hebrewand Arabic-speaking pre-service teachers in Israel. International Journal of Science Education, 25(7), 821-846.

Schibeci, R. (2006). Student images of scientists: What are they? Do they matter? Teaching Science, 52(2), 12-16.

Schibeci, R. A. (1986). Images of science and scientists and science education. Science Education, 70(2), 139-149.

Schibeci, R.A. \& Sorensen, I. (1983). Elementary school children's perceptions of scientists. School Science and Mathematics, 83(1), 14-20.

She, H.C. (1995). Elementary and middle school students' image of science and scientists related to current science textbooks in Taiwan. Journal of Science Education and Technology, 4(4), 283-294.

Silver, A. \& Rushton B.S. (2008). Primary-school children's attitudes towards science, engineering and technology and their images of scientists and engineers. Education, 36(1), 51-67.

Song, J. \& Kim, K. S. (1999). How Korean students see scientists: the images of the scientist. International Journal of Science Education, 21(9), 957-977.

Symington, D. \& Spurling, H. (1990). The Draw-A-Scientist Test: Interpreting the data. Research in Science and Technological Education, 8(1), 75-77.

Şen-Gümüş, B. (2009). Bilimsel öykülerle fen ve teknoloji eğitiminin ögrencilerin fen tutumlarına ve bilim insanı imajlarına etkisi [The effects of the science and technology education with scientific stories, to the students attitude towards science and their images of scientists]. (Unpublished master thesis). Hacettepe University, Ankara, Turkey.

Thomas, J. \& Hairston, R.A. (2003). Adolescent students' images of an environmental scientist: An opportunity for constructivist teaching. Electronic Journal of Science Education, 7(4), 1-25.

Turgut, H. (2009). Pre-service science teachers' perceptions about demarcation of science from pseudoscience. Education and Science, 34(154), 50-68.

Türkmen, H. (2008). Turkish primary students' perceptions about scientist and what factors affecting the image of the scientists. Eurasia Journal of Mathematics, Science \& Technology Education, 4(1), 55-61.

Ünver, A.O. (2010). Bilim insanlarını algılama: İlköğretim 5. sınıf öğrencileri ile son sınıf öğretmen adaylarının karşılaştırılması [Perceptions of Scientists: A Comparative Study of Fifth Graders and Fourth Year Student Teachers]. Necatibey Faculty of Education, Electronic Journal of Science and Mathematics Education, 4(1), 11-28.

Yontar-Toğrol, A. (2000). Öğrencilerin bilim insanı ile ilgili imgeleri [Student images of scientist]. Education and Science, 25(118), 49- 57. 